\title{
Assessing illicit substance use in schizophrenia: The relationship between self report and detection by hair analysis
}

DOI:

10.1016/j.schres.2009.07.020

Link to publication record in Manchester Research Explorer

Citation for published version (APA):

Haddock, G., Cross, Z., Beardmore, R., Tarrier, N., Lewis, S., Moring, J., \& Barrowclough, C. (2009). Assessing illicit substance use in schizophrenia: The relationship between self report and detection by hair analysis.

Schizophrenia Research, 114(1-3), 180-181. https://doi.org/10.1016/j.schres.2009.07.020

Published in:

Schizophrenia Research

\section{Citing this paper}

Please note that where the full-text provided on Manchester Research Explorer is the Author Accepted Manuscript or Proof version this may differ from the final Published version. If citing, it is advised that you check and use the publisher's definitive version.

\section{General rights}

Copyright and moral rights for the publications made accessible in the Research Explorer are retained by the authors and/or other copyright owners and it is a condition of accessing publications that users recognise and abide by the legal requirements associated with these rights.

\section{Takedown policy}

If you believe that this document breaches copyright please refer to the University of Manchester's Takedown Procedures [http://man.ac.uk/04Y6Bo] or contact uml.scholarlycommunications@manchester.ac.uk providing relevant details, so we can investigate your claim.

\section{OPEN ACCESS}


Letter to the Editor

\section{Assessing illicit substance use in schizophrenia: The relationship between self report and detection by hair analysis}

\section{Dear Editor,}

There is much literature about methods for the detection and assessment of illicit substances. The most common methods tend to fall into those made by self report (Sobell and Sobell, 1979), information gathered from informants (Fal-Stewart et al., 2000) and biochemical methods e.g. analysis of hair samples and urine testing (Jaffee et al., 2008; McPhillips et al., 1998). Reliability and validity of these methods are variable and vary across substances (e.g. Tassiopoulos et al., 2006). Substance use is a significant problem for people with schizophrenia although there has been little investigation of assessment methods for this population. General findings suggest that self report methods may have advantages over biochemical methods. The Time Line Follow Back self report method (TLFB; Sobell and Sobell, 1979) has been used in non-psychosis populations and has good reliability and validity. It has not been used extensively with people with psychosis; however, Barrowclough et al. (2001) found it to be acceptable and practical for use with this client group in a prior study, with good concurrent validity.

We investigated the relationship between self report methods of substance use assessment (TLFB) and detection from hair analysis in people dually diagnosed with psychosis and substance misuse problems. Thirty six participants with DSM-IV diagnosis of schizophrenia and substance abuse or dependence taking part in a trial of psychological therapy (Haddock et al., 2003) were recruited. Demographic details, TLFB assessment of self-reported substance use over a retrospective 3 month period and hair samples (approximately $2 \mathrm{~cm}$ long) were collected. Hair samples were analysed by a specialist hair analysis company (TrichoTech Ltd) using procedures to detect the presence of cannabis, amphetamine, LSD, heroin, cocaine. It was hypothesised that self report methods would reveal similar rates of detection to that revealed by hair analysis.

Ninety two of the participants were male, the mean age was 31 years (SD 10 years) and all were of white European ethnicity. One participant refused to supply a hair sample, 4 samples were insufficient in quantity on which to analyse and 3 samples were missing. TLFBs were available on all participants. As a result, hair and TLFB assessment were available on 28 participants (78\%).
Rates of substance use on TLFB and detection from hair are illustrated in Table 1 for cannabis and amphetamines. There was agreement between self report and hair analysis on the presence of cannabis in 5 participants, and on the absence of cannabis for 12 people. However, 10 further participants selfreported using cannabis which was not detected by hair analysis. In addition, one participant had cannabis detected by hair analysis although they had not self-reported this. If hair analysis were considered a gold standard for assessing the validity of the TLFB method, these data show that sensitivity of the TLFB at detecting cannabis (against the hair detection) was $83 \%$ and the specificity was $55 \%$ suggesting that self report was producing a greater number of positives than hair analysis was detecting. Similarly, if TLFB were considered to be a gold standard, the sensitivity of the hair analysis against the TLFB was $33 \%$, whereas the specificity was $92 \%$.

For amphetamines, a similar picture was seen, with 21 participants self reporting no substance use which was also detected by hair analysis. Seven participants reported that they used amphetamines, of which hair analysis detected use in 4 of these but failed to detect use in the other 3 samples. Sensitivity for the TLFB against the hair analysis was 100\% and specificity was $88 \%$. Sensitivity of the hair analysis against the TLFB was $57 \%$ and specificity was $100 \%$.

Self report of illicit substance use using TLFB methodology resulted in greater endorsement of use of amphetamines and cannabis than that detected using hair analysis. The self report and detection of other substances were too low to make any firm conclusions. The findings for cannabis and amphetamines, however, suggest that although hair analysis is quite specific in detecting substances, it lacks sensitivity and this makes it likely to result in a high rate of false negatives. One explanation could

Table 1

Self report and hair analysis rates of detection for cannabis and amphetamines.

\begin{tabular}{lllr}
\hline & \multicolumn{2}{c}{ Hair analysis result } & Total \\
\cline { 2 - 3 } & Absent & Present & \\
\hline Cannabis & 12 & 1 & 13 \\
Self report TLFB absent & 10 & 5 & 15 \\
Self report TLFB present & 22 & 6 & 28 \\
Total & & & \\
Amphetamines & 21 & 0 & 21 \\
Self report TLFB absent & 3 & 4 & 7 \\
Self report TLFB present & 24 & 4 & 28 \\
Total & & & \\
\hline
\end{tabular}


be that TLFB methodology encouraged over-reporting of substance use, however, the motivation for over-reporting of substances in this population seems unlikely. Findings suggest then, that although hair analysis may have some uses in confirming some substance use in this population, and would be extremely useful when specificity is paramount e.g. in forensic cases, TLFB methodology may be a more sensitive measure for detection of amphetamines and cannabis. This may be a more useful function in clinical practice and research as it allows not only the detection of substance use with good sensitivity but will facilitate clinicians and researchers to explore and assess the nature of the substance use in greater detail.

\section{References}

Barrowclough, C., Haddock, G., Tarrier, N., Lewis, S., Moring, J., O'Brien, R., Schofield, N., McGovern, J., 2001. Randomized controlled trial of motivational interviewing, cognitive behaviour therapy, and family intervention of patients with co-morbid schizophrenia and substance use disorder. Am. J. Psychiatry 158, 1706-1713.

Fal-Stewart, E., O'Farrell, T.J., Freitas, T.T., McFarline,S.K., Rutigliano, P., 2000. The timeline follow-back reports of psychoactive substance use by drug abusing patients: psychometric properties. J. Consult. Clin. Psychol. 68 (1), 134-144.

Haddock, G., Barrowclough, C., Tarrier, N., Moring, J., O'Brien, R., Schofield, N., Quinn, J., Palmer, S., Davies, L., Lowens, I., McGovern, J., Lewis, S., 2003. Cognitive-behavioural therapy and motivational intervention for schizophrenia and substance misuse. Br. J. Psychiatry 183, 418-426.

Jaffee, W.B., Trucco, E., Teter, C., Levy, S., Weiss, R.D., 2008. Focus on alcohol \& drug abuse: ensuring validity in urine drug testing. Psychiatr. Serv. 59, 140-149.
McPhillips, M.A., Strang, J., Barnes, T.R.E., 1998. Hair analysis. new laboratory ability to test for substance use. Br. J. Psychiatry 173 (10), 287-290.

Sobell, L.C., Sobell, M.B., 1979. A self feedback technique to monitor drinking behaviour in alcoholics. Behav. Res. Theory 11, 237-238.

Tassiopoulos, K., Bernstein, J., Heeren, T., Levenson, S., Hingson, R., Bernstein, E., 2006. Predictors of disclosure of continued cocaine use. Addict. Behav. 31 (1), 80-89.

Gillian Haddock*

Zoe Cross

Ruth Beardmore

Nicholas Tarrier

Jan Moring

Christine Barrowclough

Division of Clinical Psychology, School of Psychological Sciences, Zochonis Building, The University of Manchester, Oxford Road, Manchester, M13 9PL, UK

*Corresponding author. Tel.: +44 161275 8485;

fax: +441612758487.

E-mail address: Gillian.Haddock@Manchester.ac.uk

(G. Haddock).

Shôn Lewis

Community Based Medicine, University Place, The University of Manchester, Oxford Road, Manchester, M13 9PL, UK

7 May 2009 